\title{
Patterns of cleaner wrasse density among three regions of the Pacific
}

\author{
Céline Arnal ${ }^{1, *}$, Serge Morand $^{1}$, Michel Kulbicki ${ }^{2}$ \\ ${ }^{1}$ Centre de Biologie et d'Ecologie Tropicale et Méditerranéenne, Laboratoire de Biologie Animale (UMR 5555 CNRS), \\ Université de Perpignan, F-66860 Perpignan Cedex, France
}

${ }^{2}$ ORSTOM B.P. A5, Nouméa, New Caledonia

\begin{abstract}
Despite years of studies, cleaning interactions between cleaner and host fishes are still not well understood. Relating density of cleaner wrasse with fish species richness, density and biomass across different geographic localities may help to better understand cleaner/host fish relationships. In this study, we explored the patterns of variation in cleaner wrasse densities among 3 regions of the Pacific. An increasing gradient of cleaner wrasse density was observed from Ouvéa (West Pacific) to Tuamotu (Central Pacific). This increasing density followed a decreasing gradient in the density of other reef fishes. Within each locality, densities of cleaner wrasse were positively correlated with densities of reef fishes. In order to better understand the underlying influences on the density of cleaner wrasse, the densities of reef fishes were examined in relationship to fish body size, fish sedentary, territorial and mobile behavior, and gregariousness. We showed that there is no relationship between the density of cleaner wrasse and host fish sedentary, territorial or mobile behavior, but that there are positive relationships with both host fish body size and host gregariousness. We hypothesize that the positive relationships are closely linked with fish ectoparasite loads.
\end{abstract}

KEY WORDS: Cleaner fish - Labroides spp. Biogeography - Indo-Pacific · Fish density · Fish body size . Fish gregariousness

\section{INTRODUCTION}

Cleaning symbioses have been widely described in the literature (Feder 1966, Youngbluth 1968, Hobson 1971, Losey 1972, 1974, 1979, 1993, Gorlick et al. 1978, Itzkowitz 1979, Poulin 1993, Grutter 1995, 1996a,b, Losey et al. 1995, Arnal 1996, Poulin \& Grutter 1996, Grutter \& Poulin 1998a). This relationship involves a cleaner fish, which removes ectoparasites, diseased tissues and mucus from the surface of a client fish. Although this relationship has been described as a textbook example of mutualism, the cost and benefit for cleaners and hosts are not well understood (Losey et al. 1995, Poulin \& Grutter 1996, Arnal \& Côté 1998, Grutter \& Poulin 1998a). Cleaning interactions occur usually at cleaning stations where host fishes visit a settled cleaner fish. Many fish species have been described as cleaners; among these species, the

\footnotetext{
·E-mail: arnal66@gala.univ-perp.fr
}

cleaner wrasses belonging to the Labridae family are quite common (van Tassel et al. 1994).

Surprisingly, although many studies have investigated the nature of cleaning symbioses, few efforts have been made to understand interactions between cleaner fishes and other members of the fish community (Arnal \& Côté 1998). Moreover, factors that may influence cleaner fish densities are poorly known. Cleaning stations were, at first, described as determining the distribution and density of fish populations (Slobodkin \& Fishelson 1974). Johnson \& Ruben (1988) emphasized that the density and diversity of reef fishes plus the availability of suitable substrates promote the density and diversity of cleaners, rather than the reverse. Therefore, increased knowledge of the geographical variation in cleaner fish densities may open new avenues toward better understanding of cleaner/ host fish relationships.

In the Pacific, fish species richness, density and biomass show variations between biotopes (Kulbicki 1997) 
Comparing cleaner wrasse density with these 3 factors in different geographic localities can help to answer several questions. Firstly, is the density of cleaner wrasse subject to geographical variation? Secondly, within a region, considering that reef fishes are potential hosts for the cleaners, does the density of cleaner wrasse vary with reef fish density, number of species or biomass, which should represent the food available for cleaners? Finally, does cleaner density vary with fish densities according to the body size, the sedentary, territorial or mobile behaviors, or the gregariousness of fishes?

Fish body sizes may affect cleaner wrasse density. Several studies have shown that ectoparasite load is often positively correlated with fish body size (Poulin 1993, Grutter 1995, Poulin \& Rohde 1997, Sasal et al. 1997. Sasal \& Morand 1998). Therefore, we hypothesize that cleaner wrasses should prefer sites or localities where large fishes occur.

Reef fish sedentary, territorial and mobile behaviors may have an effect on cleaner fish density. Studies on Caribbean cleaner fishes (Thalassoma bifasciatum and Elacathinus sp.) revealed that territorial fishes, by chasing reef fishes, appear to have a negative influence on cleaner fish activity when they are settled close to each other (Itzkowitz 1979, Arnal 1996, Arnal \& Côté 1998). Mobile fishes could also be less attractive than sedentary fishes for cleaner fish, as they would not represent a faithful clientele. Moreover, as parasite load, generally, is high in sedentary hosts (Côté \& Poulin 1995), cleaner fishes should prefer sedentary client fishes.

Finally, fish gregariousness is known to be positively correlated with parasite species richness (Côté \& Poulin 1995, Sasal \& Morand 1998); solitary fishes are less parasitized than fishes living in large groups. Therefore, solitary fishes could be less attractive for cleaner wrasses than are gregarious fishes.

Our aim in the present study was to test for relationships between cleaner wrasse density and reef fish communities within and among regions. We were also looking for possible interactions with fish body size, fish sedentary, territorial or mobile behavior, and gregariousness of fishes.

\section{MATERIALS AND METHODS}

The cleaner wrasse genus Labroides (Labridae) was investigated. Four species of cleaners were chosen, $L$. dimidiatus, L. bicolor, L. pectoralis and L. rubrolabiatus (van Tassel et al. 1994). The study was carried out in 3 different localities: Tuamotu $(n=130)$, Tonga Tapu ( $n=45$ ) and Ouvéa ( $n=105)$, where $n$ is the number of sites at each locality. The descriptions of these regions are given respectively by Harmelin-Vivien et al. (1997), Matoto et al. (1997) and Kulbicki (1997). Within each region sampling areas were designated according to the prominent type of reef present. Within a certain reef type the sites were separated by a minimum of 1 nautical mile and a maximum of 3 ; their precise locations were chosen at random. At each site, underwater visual surveys were performed in transects. The number of transects per site was 4 in Tuamotu, 1 in Tonga Tapu and 2 in Ouvéa. In each transect all fish were recorded visually (see Letourneur et al. 1997 for details of the method).

Fish density (number of fish $\mathrm{ha}^{-1}$ ), species richness (number of species transect ${ }^{-1}$ ) and biomass ( $g \mathrm{ha}^{-1}$ ) were estimated for each station at each locality (Burnham et al. 1980, Buckland et al. 1993). In brief, a $50 \mathrm{~m}$ transect line was first laid on the bottom. Then a diver swam along this transect and recorded all the fish he observed. For each observation, the diver noted the species, the size of the fish and its perpendicular distance from the transect line. Fish size was estimated in $1 \mathrm{~cm}$ class intervals for fish less than $10 \mathrm{~cm}$ in length, $2 \mathrm{~cm}$ class intervals for fish between 10 and $30 \mathrm{~cm}$, and $5 \mathrm{~cm}$ class intervals for fish longer than $30 \mathrm{~cm}$. Distances from the transect line were noted in $1 \mathrm{~m}$ intervals for up to $5 \mathrm{~m}$, then in $2 \mathrm{~m}$ intervals for distances between 5 and $10 \mathrm{~m}$; fish beyond $10 \mathrm{~m}$ were recorded in $5 \mathrm{~m}$ intervals. Densities were estimated using distance-sampling algorithms (Buckland et al. 1993) provided in the program DISTANCE (Laake et al. 1994). Biomasses were calculated by using the same algorithms applied to weights instead of numbers. To obtain weight, length-weight relationships were used from ORSTOM's data base FISHEYE (Labrosse et al. 1997).

Fish densities were also estimated in relationship to fish body size, host sedentary, territorial and mobile behavior, and gregariousness. Fishes were divided into 3 size classes: small fishes $(<7 \mathrm{~cm})$, medium fishes ( 7 to $30 \mathrm{~cm}$ ), and large fishes $(>30 \mathrm{~cm}$ ). Territorial fish are those which defend a territory (i.e. many Pomacentridae) or which roam over a fixed territory (i.e. most Chaetodontidae). The term sedentary was used to designate fish that stay within a limited range, usually not leaving their reef for long periods (e.g. most Serranidae). Species were considered mobile if they moved over large expanses of reef; this category included fishes which do not roam from one reef to another, if reefs are separated by large expanses of soft sediment or deep water (e.g. Scaridae, many Lutjanidae or Lethrinidae), but also fishes which cover great distances and are not attached to a particular reef (e.g. most Carangidae, some Lethrinidae). Finally, 3 different fish group sizes were used to distinguish gregariousness: solitary or paired fishes (1 or 2 fishes), 
fishes living in small groups (from 3 to 20 fishes), and fishes living in large groups (more than 20 fishes).

All analyses were performed using non-parametric statistics since our data did not meet the assumption of parametric testing. Kruskal-Wallis 1-way ANOVA by ranks was used for comparisons between the 3 localities. A Bonferroni correction adjusted the level of significance from $\alpha=0.05$ to $\alpha=0.01$. Tukey unequal sample size HSD tests were used to detect differences between localities $(\alpha=0.05)$. Associations within each locality were determined using Spearman's rank correlation coefficient $(\alpha=0.05)$. Because of the relatively small number of stations visited in Tonga Tapu $(n=45)$, all results involving this locality should be considered with caution.

\section{RESULTS}

\section{Variations in cleaner wrasse densities, and reef fish densities, species richness and biomass among the three localities}

There was a significant difference in densities of cleaner wrasse among Tuamotu, Tonga Tapu and Ouvéa reefs (Kruskal-Wallis test: $H[2,282]=35.47, \mathrm{p}<$ 0.0001 ). Cleaner wrasse densities (mean $\pm \mathrm{SE}$ ) differed significantly between Tuamotu (125 \pm 15 cleaners ha $\left.{ }^{-1}\right)$ and Ouvéa $\left(35 \pm 8\right.$ cleaners ha ${ }^{-1}$ ) (Tukey HSD tests: $p<$ $0.001)$, and between Tonga Tapu (123 \pm 36 cleaners ha ${ }^{-1}$ ) and Ouvéa (Tukey HSD tests: $p=0.005$ ) (Fig. 1). The highest densities occurred at Tuamotu and Tonga Tapu; at these 2 locations the mean number of cleaners did not differ significantly (Tukey HSD test). The lowest mean density was observed at Ouvéa.

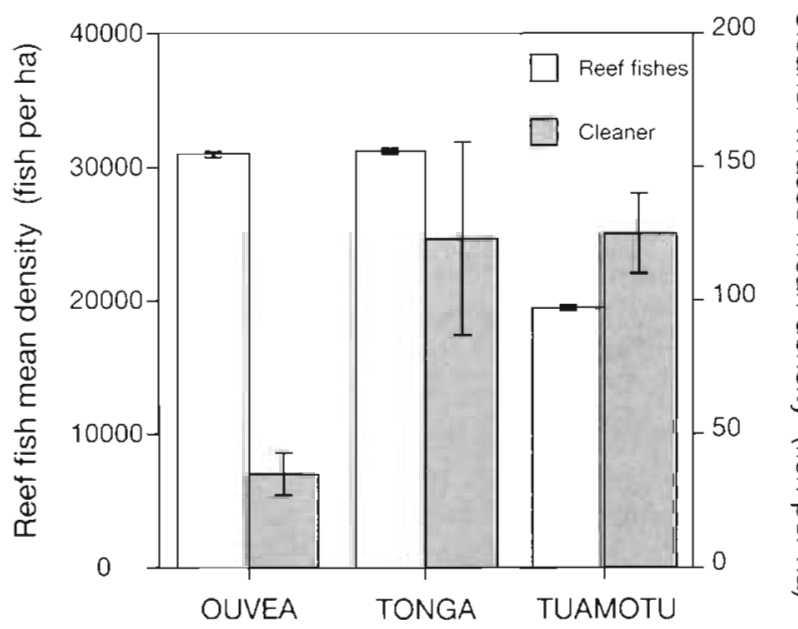

Fig. 1. Mean densities of reef fishes and cleaner wrasse ( \pm standard error) at Ouvéa (105 sites), Tonga Tapu (45 sites) and Tuamotu (130 sites)
Between the 3 localities, only reef fish densities varied significantly (Kruskal-Wallis test: $H[2,282]=13.52$, $p=0.001$ ). There were no differences in species richness or fish biomass between Tuamotu, Tonga Tapu and Ouvéa reefs (Kruskal-Wallis tests). Fish densities differed between Tuamotu and Ouvéa (Tukey HSD tests: $p=0.026)$, with a greater mean $( \pm S E)$ number of fish at Ouvéa $\left(30922 \pm 482\right.$ fishes $\left.h^{-1}\right)$ than at Tuamotu (19331 \pm 113 fishes ha ${ }^{-1}$ ) (Fig. 1). No difference in reef fish density between Ouvéa and Tonga Tapu (31082 \pm 293 fishes ha ${ }^{-1}$, Tukey HSD tests) was recorded.

Variations in reef fish densities in relationship to their body size, sedentary, territorial and mobile behavior, and gregariousness among the three localities

Densities of small fish differed between Tuamotu, Tonga Tapu and Ouvéa (Kruskal-Wallis test: $H[2,282]$ $=8.76, \mathrm{p}=0.012 \mathrm{j}$. Medium and large fish densities were also different between the 3 localities (KruskalWallis test: all $\mathrm{p}<0.001$ ). When using Tukey HSD tests, only the density of medium sized fish showed significant differences between Tuamotu, Tonga Tapu and Ouvéa. There were more medium sized fishes in Tonga Tapu than in Tuamotu (Tukey HSD tests: $p=$ 0.009) (Table 1). Moreover, there was no difference between medium fish density in Ouvéa and Tonga Tapu (Tukey HSD tests)

The densities of mobile fish in Ouvéa, Tonga Tapu and Tuamotu were similar (Kruskal-Wallis test: $H[2$, $282]=1.22, p=0.54$ ). Densities of territorial and sedentary fish showed a significant difference among the 3 localities (Kruskal-Wallis test: all $\mathrm{p}<0.001$ ). However, these differences in densities were confirmed only for sedentary fish by Tukey HSD tests. There were more sedentary fishes at Ouvéa than at Tuamotu. No difference was found between Ouvéa and Tonga Tapu for sedentary fish densities (Tukey HSD tests) (Table 1).

The densities of fish from large size groups were the same in Ouvéa, Tonga Tapu and Tuamotu (KruskalWallis test: $p=0.64$ ). However, Tukey HSD tests showed a significant difference between Tuamotu and Ouvéa $(p=0,005)$. Densities of solitary or paired fish and fish from small groups differed at the 3 localities (Kruskal-Wallis test: all $\mathrm{p}<0.0001$ ) (Table 1). Tukey HSD tests showed that more solitary or paired fishes were found in Tonga Tapu than in Ouvéa and Tuamotu (Tukey HSD tests: all $p<0.0001$ ); no differences were found between Ouvéa and Tuamotu (Tukey HSD tests: $p=0.99$ ). Finally, fish from small sized groups showed significant differences in their densities at the 3 localities (Tukey HSD tests: all $\mathrm{p}<0.006$ ). 
Table 1 Mean densities (t standard error) of reef fishes according to their body size (small, medium and large sized fishes), sedentary, territorial or mobile behaviors, and gregariousness (solitary or paired fishes, fishes from small and large sized groups) at the 3 locations: Ouvéa (105 sites). Tonga Tapu (45 sites) and Tuamotu (130 sites). (NS: no significant difference between the 3 localities, S: significant difference between the 3 locations shown by Kruskal-Wallis test or Tukey HSD tests only; SS: significant difference between the 3 locations shown by Kruskal-Wallis and Tukey HSD tests)

\begin{tabular}{|c|c|c|c|c|}
\hline & Ouvéa & Tonga Tapu & Tuamotu & Significance \\
\hline \multicolumn{5}{|l|}{ Body size } \\
\hline Small & $16688 \pm 3683$ & $13922 \pm 2046$ & $9659 \pm 776$ & NS \\
\hline Medium & $12830 \pm 1527$ & $15619 \pm 1372$ & $8858 \pm 583$ & $\mathrm{SS}$ \\
\hline Large & $549 \pm 66$ & $255 \pm 52$ & $706 \pm 80$ & $\mathrm{~S}$ \\
\hline \multicolumn{5}{|l|}{ Behavior } \\
\hline Territorial & $5494 \pm 2038$ & $9184 \pm 2166$ & $5714 \pm 534$ & $\mathrm{~S}$ \\
\hline Sedentary & $16258 \pm 2976$ & $14186 \pm 1395$ & $7289 \pm 738$ & SS \\
\hline Mobile & $8988 \pm 1179$ & $7122 \pm 718$ & $6324 \pm 413$ & NS \\
\hline \multicolumn{5}{|l|}{ Gregariousness } \\
\hline 1 or 2 fishes & $2379 \pm 196$ & $6224 \pm 489$ & $2341 \pm 152$ & SS \\
\hline Small group & $4107 \pm 353$ & $10042 \pm 91.5$ & $6489 \pm 588$ & $\mathrm{SS}$ \\
\hline Large group & $23161 \pm 4570$ & $12287 \pm 2087$ & $10330 \pm 703$ & $\mathrm{~S}$ \\
\hline
\end{tabular}

\section{Variations in cleaner wrasse densities and fish densities, species richness and biomass within reefs}

Densities of cleaner wrasse were significantly correlated with reef fish densities in Tuamotu $\left(\mathrm{r}_{\mathrm{s}}=0.473, \mathrm{p}<\right.$ $0.0001)$, Tonga Tapu $\left(\mathrm{r}_{\mathrm{s}}=0.412, \mathrm{p}=0.003\right)$ and Ouvéa $\left(r_{s}=0.412, p<0.0001\right)$. Densities of cleaner wrasse were correlated with densities of reef fish according to their size (small, medium and large fish) and their gregariousness (solitary, small group size and large group size) in Tuamotu and Ouvéa (Spearman's rank correlation coefficient: all significant) (Table 2). Cleaner wrasse density in Tonga Tapu was correlated with the density of large sized fish. When we looked at gregariousness, only solitary or paired fish were significantly correlated with densities of cleaner wrasse at the 3 locations. Fish from small and large sized groups were not correlated with densities of cleaner wrasse at Tonga Tapu (Table 2). The densities of cleaner wrasse were significantly correlated with the density of sedentary fishes at the 3 locations. Cleaner wrasse density was not correlated with densities of mobile fishes or territorial fishes at Tonga Tapu, but these correlations were significant at Ouvéa and Tuamotu. Densities of cleaner wrasse were significantly correlated with reef fish species richness in Tuamotu $\left(\mathrm{r}_{\mathrm{s}}=0.784, \mathrm{p}<\right.$ $0.0001)$, Tonga Tapu $\left(\mathrm{r}_{\mathrm{s}}=0.542, \mathrm{p}<0.0001\right)$ and Ouvéa $\left(\mathrm{r}_{\mathrm{s}}=0.577, \mathrm{p}<0.0001\right)$. Finally, significant correlations were also observed between densities of cleaner wrasse and biomass of reef fishes in Tuamotu $\left(r_{\mathrm{s}}=0.474, p<0.0001\right)$, Tonga Tapu $\left(r_{\mathrm{s}}=0.361, p=0.012\right)$ and Ouvéa $\left(r_{\mathrm{s}}=0.439\right.$, $\mathrm{p}<0.0001$ ).

\section{DISCUSSION}

Similar biotopes were found in the 3 regions studied. However, one should be aware of some differences in habitat and in sampling design between these 3 regions. In Ouvéa, the atoll has a larger percentage of hard substrate (Kulbicki 1997) than Tonga Tapu or the atolls of Tuamotu. Ouvéa, like Tonga Tapu, has many passes, and the oceanic influence is probably much greater than in the atolls of Tuamotu. The size of the atolls also plays a role. In Tuamotu the atolls studied ranged from 1 to $315 \mathrm{~km}^{2}$, whereas Tonga Tapu covers

Table 2. Correlations (Spearman's rank correlation coefficient, $r_{s}$ ) between cleaner wrasse densities and reef fish densities according to their body size (small, medium and large sized fishes), sedentary, territorial or mobile behaviors, and gregariousness (solitary or paired fishes, fishes from small and large groups) at the 3 locations: Ouvea ( $n$ $=105)$, Tonga Tapu $(n=45)$ and Tuamotu $(n=130)$. Probability values are given in parentheses

\begin{tabular}{|llll|}
\hline & \multicolumn{1}{c}{ Ouvéa } & Tonga Tapu & \multicolumn{1}{c|}{ Tuamotu } \\
\hline $\begin{array}{l}\text { Body size } \\
\text { Small }\end{array}$ & $0.24(<0.0001)$ & $0.35(0.014)$ & $0.40(<0.0001)$ \\
$\quad \begin{array}{l}\text { Medium } \\
\text { Large }\end{array}$ & $0.53(<0.0001)$ & $0.31(0.032)$ & $0.40(<0.0001)$ \\
Behavior & $0.39(0.0001)$ & $0.55(<0.0001)$ & $0.37(0.0006)$ \\
$\quad$ & & & \\
Territorial & $0.40(<0.0001)$ & $0.36(0.013)$ & $0.38(<0.0001)$ \\
Sedentary & $0.32(<0.0001)$ & $0.40(0.005)$ & $0.49(0.0001)$ \\
Mobile & $0.43(0.0002)$ & $0.09(0.548)$ & $0.35(<0.0001)$ \\
Gregariousness & & & \\
$\quad$ or 2 fishes & $0.63(<0.0001)$ & $0.54(<0.0001)$ & $0.61(<0.0001)$ \\
Small group & $0.39(<0.0001)$ & $0.17(0.257)$ & $0.58(<0.0001)$ \\
Large group & $0.40(0.002)$ & $0.32(0.290)$ & $0.30(<0.0001)$ \\
\hline
\end{tabular}


approximately $400 \mathrm{~km}^{2}$ and Ouvéa $900 \mathrm{~km}^{2}$. Galzin et al. (1994) have demonstrated that fish diversity is a function of atoll size. Therefore, diversity should be higher in Ouvéa than in Tonga Tapu or Tuamotu. This was indeed observed, but not at a significant level. Another important difference is the amount of fishing going on at a certain area. Tonga Tapu supports approximately 150 persons $\mathrm{km}^{-2}$ of lagoon, Ouvéa, 3 persons $\mathrm{km}^{-2}$, and Tuamotu approximately 0.5 persons $\mathrm{km}^{-2}$. Jennings \& Polunin (1995) found that fishing pressure was an important factor determining the structure of fish assemblages on small islands in the Fijis. In particular, large piscivores and macrocarnivores (Serranidae, Lethrinidae and Lutjanidae) were affected.

The depth range in Tonga Tapu was from 0.5 to $10 \mathrm{~m}$ whereas in Ouvéa and Tuamotu the range studied was 0.5 to $20 \mathrm{~m}$. This may be responsible for some of the observed differences in the structures of the fish assemblages. Indeed, the abundance of herbivores tends to decrease with depth, whereas planktivores show the opposite trend. Herbivores will also increase with hard substrate cover (Letourneur et al. 1997).

An increasing gradient of cleaner wrasse density was observed from Ouvéa to Tuamotu, whereas there was a decreasing gradient in the density of other reef fish. Within each locality, densities of cleaner wrasse were positively correlated with densities of reef fishes. Removal experiments on cleaners showed that cleaner wrasse do not seem to have an influence on the abundance of reef fishes (Grutter 1997a), but Johnson \& Ruben (1988) demonstrated that fish densities may influence the occurrence of cleaner fishes.

These contrary results, i.e. a positive relationship between cleaner densities and fish densities within localities and a negative relationship between localities, may be explained in many ways. For instance, the availability of suitable substrates promotes cleaner wrasse density on a reef (Johnson \& Ruben 1988); hence, the observed differences between the 3 localities may reflect a difference in substratum between Ouvéa, Tonga Tapu and Tuamotu. One of the striking features of the atolls in Tuamotu is the patchy distribution of reefs, compared with the continuous reefs observed in Ouvéa and to a lesser extent Tonga Tapu. Consequently, the patchiness of the reefs at Tuamotu may help to separate competing fish and therefore induce higher densities of cleaner wrasses.

Geographical variation may also have an influence on cleaner wrasse distribution. Reef fish diversity decreases from the West to the Central Pacific. However, some families show the opposite trend, in particular the Labridae, which have a higher relative diversity in the Central Pacific (Kulbicki \& Rivaton 1997).
This may in part explain the importance of the cleaner wrasses in Tuamotu compared to Tonga Tapu and Ouvéa, which are both much further west.

Johnson \& Ruben (1988) also noted the dependence of cleaner fish density on the concentration of potential hosts. The present study clearly indicates that cleaner wrasse densities are correlated with overall reef fish densities, within each locality, but that the magnitude of this relationship depends on the region. However, cleaner wrasse density may be more influenced by the quality than by the number of potential hosts. As cleaner wrasses primarily feed on ectoparasites from the host's body (Youngbluth 1968, Grutter 1995, $1996 a, b, 1997 b, c$, Grutter \& Poulin 1998b), most of the observations should be based on the relationships between cleaners and ectoparasite populations, which depend directly on the host fish propensity to be parasitized (Gorlick et al. 1978). The relationship between fish density and ectoparasite loads has never been studied.

Ectoparasite community richness is primarily determined by water temperature (Poulin \& Rohde 1997) and follows a latitudinal gradient. The temperatures in these 3 regions are not well documented. However, in Ouvéa the range is between 19 and $29^{\circ} \mathrm{C}$ with strong oceanic input, whereas in the shallower atolls of Tuamotu the water temperature ranges from 22 to $32^{\circ} \mathrm{C}$ and there is much less oceanic influence. Tonga Tapu is probably intermediate. Unfortunately, we have no data on ectoparasite densities, nor on ectoparasite species richness, at the 3 localities.

In order to better understand the influences on the density of cleaner wrasse, the densities of reef fishes were considered in relationship to fish body size, fish sedentary, territorial and mobile behaviors, and gregariousness. In the following, we will only discuss patterns showing a significant relationship with cleaner wrasse density (Table 2).

In animal populations, sedentary hosts seem to be more heavily parasitized than more mobile hosts (Côté \& Poulin 1995). Therefore, we hypothesized that the densities of cleaner wrasses should be correlated with those of sedentary hosts, as such hosts would provide more food for cleaners. Moreover, cleaner wrasses should prefer reefs where sedentary fishes occur, as such fish species may represent a more faithful clientele. However, cleaner wrasses occurred in larger numbers on reefs where there were relatively few sedentary fishes. Cleaner wrasses live in sheltered habitats (Lenke 1991); therefore, the competition for refuges, especially when more sedentary fishes occur, may have a negative influence on cleaner wrasse density. Moreover, cleaner wrasses may not use fish sedentary behavior as an indication of the ectoparasitic load of their clients 
Territorial fish density was higher in Tonga Tapu than in Ouvéa and Tuamotu. On Tonga Tapu, cleaner wrasse density was also high. Although the relationship between the density of cleaner wrasses and the density of territorial fishes was not significant at this location, the 2 factors tend to be correlated. However, although cleaning by Caribbean cleaner gobies is influenced by fish territoriality (Arnal \& Côté 1998) on a local scale, it has never been observed that fish territoriality influences cleaner density on a larger scale. On the contrary, Itzkowitz (1979) observed the formation of large groups of Caribbean cleaner wrasses Thalassoma bifasciatum as a strategy against the territoriality of damselfishes. This could provide an explanation for the large numbers of both cleaner wrasses and territorial fishes at Tonga Tapu. Moreover, territorial fish usually occur in areas with dense cover (Bell \& Galzin 1984). This cover may also be used by cleaner wrasses and thus explain, in part, the relationship between territorial fish and cleaners at Tonga Tapu. Cleaner wrasse density is significantly higher at Tuamotu than at Ouvéa although the density of territorial fishes is low at both locations. Thus, we were unable to detect a specific influence of fish territoriality on cleaner wrasse density.

Variations in cleaner wrasse densities between Ouvéa, Tonga Tapu and Tuamotu according to reef fish sedentary behavior can not be explained clearly. Contrary to our hypothesis, cleaner wrasses did not occur in large numbers in areas where sedentary fish density was high and territorial fish density low. This may reflect a strategy the cleaners use to avoid competition with sedentary fishes for shelter. The relationship between fish territoriality and cleaner wrasse density remains unclear; in some cases, it may cause an aggregation of cleaner wrasse.

It is known that fish body size is positively correlated with parasite loads (Grutter 1995, Poulin \& Rohde 1997, Sasal \& Morand 1998). Therefore, we predicted positive correlations between high densities of cleaners and densities of large fishes. The variation in fish densities according to body size followed diverse trends among the reefs. The number of medium sized fish increased from Tuamotu to Ouvéa. Small fish density seemed to vary in the same way, but not significantly. The variation in the number of large fish followed an inverse gradient. There were more large fish at Tuamotu than at Ouvéa. In accordance with one of our hypotheses, cleaner wrasses were more numerous where larger fish occurred. Thus, on a regional scale, densities of cleaner wrasse follow the increase of fish body size.

Fish from small groups were less numerous in Ouvéa than in Tuamotu. High densities of cleaner wrasses were observed where densities of fish in small groups were high. This result may be explained by the positive correlation between parasite density and gregariousness found by several authors (Côté \& Poulin 1995, Sasal \& Morand 1998). This relationship, however, was not found for fish from large groups. There were more fish from large groups in Ouvéa than in Tuamotu. Our results seem to show a preference of cleaner wrasse for gregarious fish limited to small sized groups. Mooring \& Hart (1992) and Loehle (1995) argued that, in mammal populations, larger host group size should benefit from a lower parasite infestation level. If this argument is true for fish populations, then fishes living in small groups should be more parasitized than those found in larger groups, and cleaner wrasses should prefer reefs supporting large densities of fish from small sized groups.

Moreover, fish forming large schools may not be a good target for cleaner wrasses for 2 reasons. First, some of the fish forming large schools remain high in the water column and are constantly moving. Therefore, they are mostly likely inaccessible to cleaner wrasses. Secondly, most fish living in large schools are short-lived. Their densities are therefore quite variable over time, and cleaner wrasses, which have relatively long lifespans compared to this fluctuating resource, may not benefit reliably from species forming large schools.

Our results showed that cleaner wrasse densities vary among different localities according to the competition level for shelters among fishes, but also according to the quality of fish hosts. Several studies emphasized that cleaner wrasses preferentially clean client fishes harboring large numbers of ectoparasites (Poulin 1993, Grutter 1995). Accordingly, we found that cleaner wrasses were more abundant on reefs inhabited by high densities of larger fish and fish living in small groups (which are presumably more heavily parasitized). Moreover, the cleaner wrasse can either be a facultative cleaner (feeding on ectoparasites, mucus from the host's body surface and on benthic crustaceans) or a very specialized cleaner (feeding exclusively on ectoparasites from the host's body surface), depending on the food available and, therefore, the ectoparasitic loads of reef fishes (Grutter 1997b,c). Thus, we suggest that variations in densities of cleaner wrasse are closely linked to variations in ectoparasite populations.

Recent studies demonstrated that the evolution of the association between cleaner wrasses and their clients varies among client genera independent of client size (Grutter \& Poulin 1998b, Côté et al. in press). A phylogenetic control could prove conclusive. Unfortunately, our dataset did not allow us to control for phylogeny, as only 1 variable was available (there was only 1 value of density of cleaner wrasse at each site 
corresponding to other fish densities). Taking this into account, host body size may not be a good predictor of cleaner wrasse host preference. However, our results on host fish gregariousness should open new perspectives in the study of the cleaner/host fish relationship, as most recent studies considered host body size the only explanation for host preference by cleaner fishes (Poulin 1993, Grutter 1995, Arnal 1996, Poulin \& Grutter 1996).

In this study, we have assumed that cleaner wrasse densities increase with ectoparasite availability, and, thus, we assumed that cleaning activity is higher in such localities. This assumption however was not tested. Future studies investigating the cleaning behavior of cleaner wrasses should investigate whether the cleaning efficiency of wrasses is a function of their density. Furthermore, future studies should take into account composition and abundance of ectoparasites, as cleaning activity may also be influenced by these factors (Grutter 1995, 1996a,b, 1997b).

Acknowledgements. We thank A. Grutter for helpful comments on the manuscript.

\section{LITERATURE CITED}

Arnal C (1996) Interactions between cleaning gobies and territorial damselfishes on coral reefs. MSc thesis, University of East Anglia, Norwich

Arnal C, Côté IM (1998) Interactions between cleaning gobies and territonial damselfish on coral reefs. Anim Behav 55: $1429-1442$

Bell JD, Galzin R (1984) Influence of live coral cover on coralreef fish communities. Mar Ecol Prog Ser 15:265-274

Buckland ST, Anderson DR, Burnham KP, Laake JL (1993) Distance sampling - estimating abundance of biological populations. Chapman \& Hall, London

Burnham KP, Anderson DR, Laake JL (1980) Estimation of density from line transect sampling of biological populations. Wildlife Monogr 32:1-202

Côté IM, Poulin R (1995) Parasitism and group size in social animals: a meta-analysis. Behav Ecol 6:159-165

Côté IM, Arnal C, Reynolds JD (in press) Variation among fish species in posing behaviour at cleaning stations. J Fish Biol

Feder HM (1966) Cleaning symbiosis in the marine environment. In: Henry SM (ed) Symbioses. Academic Press, New York, p 335-377

Galzin R, Planes S, Dufour V, Salvat B (1994) Variation in diversity of coral reef fish between French Polynesian atolls. Coral Reefs 13:175-180

Gorlick DL, Atkins PD, Losey GS (1978) Cleaning stations as water holes, garbage dumps and sites for the evolution of reciprocal altruism. Am Nat 112:341-353

Grutter AS (1995) Relationship between cleaning rates and ectoparasite loads in coral reef fishes. Mar Ecol Prog Ser 118:51-58

Grutter AS (1996a) Parasite removal rates by the cleaner wrasse Labroides dimidiatus. Mar Ecol Prog Ser 130 $61-70$
Grutter AS (1996b) Experimental demonstration of no effect by the cleaner wrasse Labroides dimidiatus on the host fish Pomacentrus moluccensis. J Exp Mar Biol Ecol 196 285-298

Grutter AS (1997a) Effect of the removal of cleaner fish on the abundance and species composition of reef fish. Oecologia 111:137-143

Grutter AS (1997b) Spatiotemporal variation and feeding selectivity in the diet of the cleaner fish Labroides dimidiatus. Copeia 1997 (2):346-355

Grutter AS (1997c) Size-selective predation by the cleaner fish Labroides dimidiatus. J Fish Biol 50:1303-1308

Grutter AS, Poulin R (1998a) Cleaning on coral reef fishes by the wrasse Labroides dimidiatus: influence of client body size and phylogeny. Copeia 1998 (1):120-127

Grutter AS, Poulin R (1998b) Intraspecific and interspecific relationships between host size and the abundance of parasitic larval gnathiid isopods on coral reef fishes. Mar Ecol Prog Ser 164:263-271

Harmelin-Vivien M, Kulbicki M, Galzin R, Mou Tham G (1997) Reef fish community structure within atoll lagoons in French Polynesia (Tuamotu Archipelago). In: Proceeddings 5th Indo-Pacific Fish Conference, Nouméa, New Caledonia

Hobson ES (1971) Cleaning symbiosis among California inshore fishes. Fish Bull US 69(3):491-523

Itzkowitz $M$ (1979) The feeding strategies of a facultative cleaner fish: Thalassoma bifasciatum (Pisces: Labridae). J Zool 187:403-413

Jennings S, Polunin NVC (1995) Comparative size and composition of yield from six Fijian reef fisheries. J Fish Biol 46:28-46

Johnson W, Ruben P (1988) Cleaning behaviour of Bobianus rufus, Thalassoma bifasciatum, Gobiosoma evelynae and Periclimenes pedersoni along a reef depth gradient at Salt River Submarine Canyon, St Croix. Environ Biol Fish 23: $225-232$

Kulbicki M (1997) Bilan de 10 ans de recherche (1985-1995) par l'ORSTOM sur la diversité, la densité, la biomasse et la structure trophique des communautés de poissons lagonaires et récifaux en Nouvelle-Calédonie. Cybium 21: $47-79$

Kulbicki M, Rivaton J (1997) Inventaire des poissons lagonaires et récifaux de Nouvelle-Calédonie. Cybium 21(1) (Supp1):81-98

Laake JL, Buckland ST, Anderson DR, Burnham KP (1994) Distance sampling. Abundance estimation of biological populations. DISTANCE user's guide. Version $2.1 \mathrm{Col}-$ orado Cooperative Fish \& Wildlife Research Unit, Colorado State University, Fort Collins

Labrosse P, Letourneur Y, Kulbicki M, Magron F (1997) FISHEYE a new database on the biology and ecology of lagoonal and reef fishes of the South Pacific. In: Procedings 5th Indo-Pacific Fish Conference Nouméa, New Caledonia

Lenke R (1991) The opercular gland of the cleaner-wrasse Labroides dimidiatus (Labridae), a light, electron and scanning electron microscopic investivation. J Fish Biol 39:383-392

Letourneur Y, Kulbicki M, Labrosse P (1997) Spatial structure of commercial reef fish communities along a terrestrial gradient in the Northern Lagoon of New Caledonia. Environ Biol Fish 51:141-159

Loehle C (1995) Social barriers to pathogen transmission in wild animal population. Ecology 76(2):326-335

Losey GS (1972) The ecological importance of cleaning symbiosis. Copeia 1972:820-833 
Losey GR (1974) Cleaning symbiosis in Puerto Rico with comparison to the tropical Pacific. Copeia 1974:960-970

Losey GS (1979) Fish cleaning symbiosis: proximate causes of host behaviour. Anim Behav 27:669-685

Losey GS (1993) Knowledge of proximate causes aids our understanding of function and evolutionary history. Mar Behav Physiol 23:175-176

Losey GS, Mahon JL, Danilowicz BS (1995) Innate recognition by host fish of their cleaning symbiont. Ethology 100: $227-283$

Matoto S, Ledua LL, Mou Tham G, Kulbicki M, Dalzell P (1997) The aquarium fish fishery in Tonga Tapu TapuTonga Tapu. Status and recommendations for management. Country Assignment Report, South Pacific Commission

Mooring MS, Hart BL (1992) Animal grouping for protection from parasites: selfish and encounter-dilution effect. Behaviour 123:173-193

Poulin R (1993) A cleaner perspective on cleaning symbiosis. Rev Fish Biol Fish 3:75-79

Editorial responsibility: Otto Kinne (Editor),

Oldendorf/Luhe, Germany
Poulin R, Grutter AS (1996) Cleaning symbioses: proximate and adaptative explanations. BioScience 46:512-517

Poulin R, Rohde K (1997) Comparing the richness of metazoan ectoparasite communities of marine fish: controlling for host phylogeny. Oecologia 110:278-283

Sasal P, Morand S (1998) Comparative analysis: a tool for studying monogenean ecology and evolution. Int $J$ Parasitol 28:1637-1644

Sasal P, Morand S, Guégan JF (1997) Determinants of parasite species richness in Mediterranean marine fish. Mar Ecol Prog Ser 149:61-71

Slobodkin LB, Fishelson L (1974) The effect of the cleaner fish Labroides dimidiatus on the point diversity of fishes on the reef front at Eilat. Am Nat 108:369-376

van Tassel JL, Brito A, Bortone SA (1994) Cleaning behaviour among marine fishes and invertebrates in the Canary Islands. Cybium 18:117-127

Youngbluth MJ (1968) Aspect of the ecology and ethology of the cleaning fish, Labroides phtirophagus, Randall. Z Tierpsychol 25:915-932

Submitted: April 24, 1998; Accepted: October 12, 1998

Proofs received from author(s): January 22, 1999 